\title{
Deixis Marker in The Buginese Oral Literature Tau Sabbarak E: Preservation Effort of Local Identity
}

\author{
Herianah $^{1}$, Jusmianti Garing ${ }^{2}$, Jerniati $\mathrm{I}^{3}$ \\ \{herianah606@gmail.com\} \\ Balai Bahasa Sulawesi Selatan
}

\begin{abstract}
A literary work cannot be separated from deixis markers. One of the essentials of deixis function is its ability to act as a speech interpretation tool. In this case, clear deixis will lead the reader to understand the author's idea. Conversely, obscure deixis is likely to lead to an incorrect interpretation. This study aims to determine the deixis markers in the Buginese oral literature discourse entitled "Tau Sabbarak E," to preserve the Buginese community's local identity. This research uses the descriptive qualitative method. The data collection used was documentation, observation, and note-taking techniques. The data analyzed was conducted by identifying the deixis data found, classifying deixis data, analyzing data, and concluding the results. The results showed that the deixis marker in the Tau Sabbarak E story is second singular person pronoun -mu 'you,' at the word daengmu 'your brother,' lakkaimmu 'your husband,' and -kik 'you' at the word amaingekkik 'be aware of you.' The first single-person pronoun u-'aku, 'usiala' I am married, 'uita' I see, 'and usukkuru. 'I am thankful.' Furthermore, the third person pronoun plural na- is also found in the La Sabbarak E story. It seems at the word bainena 'his wife,' napalessokna lempakna 'lowered the luggage,' kedona 'his attitude,' and indokna 'mother.' The second singular person pronoun is idik 'you,' at the word idikmuto 'you too,' which refers to the character of the mother. Meanwhile, self-naming deixis is also found at the words toke 'male Chinese seller,' and punggawa 'leader' refers to La Sabbarak E. The time index is contained at the word makkukkue 'now,' cinamoha 'for a while,' maleleng wenni 'late at night,' and tette asera ele e, ' nine o'clock in the morning.' In addition, the time lexeme is not deixis, namely pitungesso 'seven days.' In this study, unfortunately, no space deixis was found. These results research is an effort to save local identity in strengthening both local and national culture.
\end{abstract}

Keywords: deixis marker, Buginese oral literature, Tau Sabbarak E

\section{Introduction}

Deixis is one of the pragmatic fields in linguistics, which is aligned with phonology, morphology, and syntax. Suppose phonology, morphology, and syntax examine the structure of language internally. In that case, deixis examines the function of using language externally, examining the language unit's communication function. Communication is built by the speaker who will take place properly if they understand using language deixis. The use of deixis in various forms of speech acts is essential. Giving meaning without paying attention to the context can lead to different interpretations. Therefore, the meaning of a speech can only be known if it has been in a language event because it is influenced by the context of the speaker's conversation situation [1]. 
The word deixis comes from the deiktikos Greek word, which means direct designation. Roman literary as the foundation of traditional grammar in the Western world translated it into Latin to become demonstrativus. Then, in English logic, the term deictic is used as direct proof that is opposed to indirect proof [2]. Furthermore, Pretce in [3] developed the concept of deixis with a broader scope known as indexicality to develop words, especially pronouns, with a language situation. In [3], Levinson studied pragmatics with five types of deixis, i.e., person deixis, place deixis, time deixis, discourse deixis, and social deixis. However, [4] only stated three types of deixis: person deixis, space deixis, and time deixis. Furthermore, the opinion stated that deixis or the English term deixis was an essential constituent in pragmatic studies, and basically, deixis consists of individual, space, and mass deixis [5].

Deixis is a term for a word or phrase that directly connects toward utterance of time, place, and person, Richards in [6]. The time deixis is the disclosure of the time point or distance from the time a speech occurs. Changes of day and night, day and week, month, and year are the basis for calculating the measuring time. In many languages, deixis is expressed in tense. [3] reviewed in some points, i.e., space that expresses the meaning of time, for instance, next Thursday or next month, yesterday, which gives the impression that time is a silent thing. While the time is not deixis, for instance, time, period, tempo, tense, and deixis time, for instance, now, yesterday, tomorrow. [7] in her thesis, it was said that tenses were grammatically unmarked. It's only marked by the lexically of adverbial times that refer to absolute and relative times. Furthermore, in [8], Levinson emphasizes that deixis concerns matters relating to language coding or grammatical features of the context of utterance or speech events, concerning matters related to interpretation that rely on speech in the context of utterance.

Research on deixis was conducted by [9] in 1984 entitled "Deiksis dalam Bahasa Indonesia." [10] also wrote "Penggunaan Deiksis dalam Perahu Nuh II Karya Aspar" in 2002. Another research was conducted on "Penanda Deiksis Waktu dalam Bahasa Makassar" in 1998. Then, [12] then wrote about "Deiksis dalam Ungkapan Pakkiok Bunting dalam Bahasa Makassar" in 2009. In addition, there is a study entitled Deixis in Novel "The Last Star" by Rick Yancey in 2018, written by [13]. This study's finding contains many expressions of human thoughts, ideas, opinions, and character messages in various situations in the text. Another deixis research was conducted by [14] in 2019 entitled "Deixis in Judith McNaught's Night Whispers Novel," written by Judith McNaught. This paper aims to examine the types of deixis, the meaning of deixis, and deixis's position in the novel. The most recent research was conducted by [15] in 2020 entitled "Deiksis dalam Kumpulan Cerpen Al-Kabuus Tinjauan Sosiopragmatik." This study examines the use of deixis in Indonesian translated texts from the source language, Arabic.

In the Buginese language, speakers of the Buginese language recognize various lexical types related to language encoding of speech contexts. Based on the time point, the disclosure of Buginese oral literature entitled Tau Sabbarak E contains categories of person, time, and space pronouns related to speech situations. This research explicitly discusses the categories of person, time, space, or the author's deixis pointers in constructing his story. Regarding the results of prior studies, it is clear that the research on "Deixis Markers in Buginese Oral Literature Tau Sabbarak E" has never been studied before. Therefore, the authors are interested in research from the deixis perspective. Thus, this study's problem is going to how is deixis in Buginese oral literature Tau Sabbarak E. The purpose of this research is to reveal the forms of deixis use in Buginese oral literature. 


\section{Research Methods}

This research uses descriptive qualitative, which aims to describe linguistic facts systematically and accurately. The Source of research data is Tau Sabbarak E, which comes from the Buginese oral literature work [16] in 1981. The data collection techniques used are documentation, observation, and note-taking techniques. The documentation technique is used to collect data obtained from written material (documented) in Buginese oral literature.

The observation technique used is reading and understanding some deixis on the Buginese oral-literary script Tau Sabbarak E. The note-taking technique used is recording the deixis types in the Buginese oral literature Tau Sabbarak E. Furthermore, analyzing the data is conducting by identifying the deixis data found, classifying deixis data, analyzing data, and concluding the results.

\section{Results and Discussion}

\subsection{Person Pronoun Deixis}

The person pronoun deixis is found in the story of Tau Sabbarak E, as contained in the following quotes.

1. Mabelamupi pole ri bola e bainena I Mani lari nok duppaiwi sibawa napalessokna lempakna. Aga nakkedana indokna, "Majak laddek uita kedona I Mani mappakua ro. I r reppa daengmu pappoleang lakkainna dek engka naduppaiwi. Manessa maega topa aga-aga napoleang. Naia lakkaimmu massularak puruk tenna ulleto pakangka”. Makkedai I Mani, "O indok, amaingekkik, dek nawedding ripakkua padatta ripancaji, idikmuto meloi na usiala. Jaji ia tona usukkuruk ri Puang Allah Taala”. (SLB:47)

His wife came down from the house to meet and lowered his luggage. Seeing this, her mother-in-law was very angry with I Mani, saying, "It is not very good in my eyes, I Mani's behavior is like that, while your sister, whose husband always brings lots of gifts, she never picks up her husband like that." Moreover, your husband, even his underwear, could not be bought it". Said I Mani, "Be aware, mom! It is not appropriate to insult us. Wasn't that your wish to marry her? That is what I am grateful for in front of God.

In data (1), there is the second singular person pronoun -mu 'you,' which is attached to the words daengmu 'your brother' and lakkaimmu "your husband." The singular second-person pronoun refers to the character La Sabbarak, or the husband of I Mani. Furthermore, the first single-person pronoun $u$ - 'aku 'attached to the word usiala 'I'm married,' uita 'I see,' and $\boldsymbol{u}$ sukkuru 'I'm grateful.' The second singular person pronoun $u$-refers to the character I Mani. The third person pronoun plural na- 'nya' is also found in the La Sabbarak story, i.e., the words bainena 'wife,' napalessokna lempakna 'passed down the luggage,' kedona 'her attitude,' which refers to the character La Sabbarak. 
While the third person pronoun is plural -na in the word indokna 'mother' refers to Mani's character. In addition, there is a second singular person pronoun at the word idik 'you,' which is found in the word idikmuto 'you too,' which refers to the Indok' mother' character. This short story is also found the second singular pronoun -kik 'you' in the word amaingekkik 'be aware of you,' which refers to the word indok 'mother.

Another person pronoun deixis in the short story can be shown in the following quote.

2. Engkana na engka siwettu nacarita La Sabbarak sibawa anak kappalake.

"Sitongeng-tongengnna La Muhammak mallagokak", adanna La

Sabbarak. "Magatosi taccoe, aga akkatata?" pakkutana anak Kappalake.

"Macinnakak mita i wanuanna tau e. Ia tona wasselekna darekku uwala modalak. Akkataku kupi ro masappa jamang”. Makkedatosi anak Kappalake' "Macinnakak usedding maccoeto ri idik, silaonni matuk, apak iak riittemak ri kappalak e, kumak ri pottanang e sappa-sappa jamang (SLB, hal.48).

One time, he spoke with the ship's crew. "La Muhammak is my family," said La Sabbarak. The ship's crew asked, "Why did you come too? La Sabbarak replied, "I want to see people's lands. The results of my fields will become my capital. I mean, when I arrive there, I will find a job. The ship's crew said, "I wish I would follow you. We are the same because I just came along on this ship. On land later, I will look at a job.

In data (2), there is a third person pronoun plural -na in the word adanna 'his word,' which refers to the La Sabbarak. While na-, which is attached to the word pakkutanana 'his question' refers to the child's character of the ship. The first-person pronoun singular (-ak) is also found in the La Sabbarak story, which is in the word mallagokak and macinnakak refer to La Sabbarak. Then, in the word of ittemak, the first pronoun singular -ak refers to the ship's crew. In addition, there is a singular second-person pronoun $u$ - 'you' at the word usedding 'I feel,' which refers to the character of the ship's crew. In data (2), a plural first pronoun also seems to the word ri idik 'on you,' which refers to La Sabbarak.

Deixis of self-naming can be seen in the story of Tau Sabbarak E as follows:

3. Makkedai I Mani, "O indok, amaingekkik, dek nawedding ripakkua padatta ripancaji, idikmuto meloi na usiala. Jaji ia tona usukkuruk ri Puang Allah Taala”. (SLB:47)

Said I Mani, "Be aware, mom! It is not appropriate to insult us. Wasn't that your wish to marry her? That is what I am grateful for in front of God.

In data (3), the self-naming deixis is found in this short story. It seems at the word indok 'mother.' The term indok for the Buginese community has become commonplace, and this term is only used in communities with regional traditions. It is different nowadays; Buginese-Makassarese children no longer use the word indok to refer mother but are more modern with the calling of mama, mammi, mace, etc. Another self-naming deixis arises at the word.

4. Lettuk i La Sabbarak ri toko e makkutananni toke we, "Magi musappaki

toke we? Loko mellau doik?". Dek, engka parellukku ki toke we".

Once there, he looked toke, who is the owner's shop. The shop clerk asked

La Sabbarak, Are you going to ask for money? La Sabbarak answered. No,

I need to meet toke for a moment.

Data (4) contains the word toke, a nickname for the shopkeeper, particularly Chinese ethnic males. Likewise, the female shopkeeper is usually called Cik. The same self-naming deixis shows in the following quote. 
5. Sisenna wennini engka engkani La Muhammad joppa-joppa ri tokona La Sabbarak. Napoleanni pakjamana maccek, de natatimpak toko e. Makkedai La Muhammak. "Talao mala barang. "Makkeda i pabbaluk e. Apak punggawa baru”. (SLB, 49).

In the evening, La Muhammak came to look at the La Sabbarak shop. He found that the workers were very busy; the store not open, said La Muhammak, "We were going to take the goods," answered the workers, "For a while, we were only cleaning and managing the shop. We were not allowed by the leader to sell."

In data (5), there is self-naming deixis at the word punggawa'leader'. The word punggawa' leader' is the personal name of La Sabbarak, who bought a shop from a toke in Singapore. La Sabbarak changed drastically to become a rich man after getting a treasure in gold and diamonds on a mountain. Thus, the word punggawa' leader' includes person pronoun selfnaming deixis.

\subsection{Time Deixis}

Time deixis in Tau Sabbarak $E$ story can be seen in the following quotes.

6. Laoni silaonna molli oto, natiwii lao ri toko e. Naia lettukna ri toko e napadeppungenni pakbalue. Makkedae makkukkue maelokkak waja manengi gajitta manuru assepettutta toko e. Pada purani nawaja gaji ulempulenna napauni makkedae ritutuk $i$ toko e ittana pitungesso. (SLB:49)

Just shut up! This is clothes for you, "said La Sabbarak. Then his friend went to call a car, and he went to his shop. When he got there, he gathered the shop workers and told them that all their salaries would be paid for this month. After that, the shop will be closed for a week.

In data (6), the time deixis marker at the word makkukkue 'now' is found. This word belongs to the deixis because it has a time point to the speaker. In addition, there is also a time that is not deixis, i.e., the word pitungesso 'seven days.' This deixis does not include time deixis because it is based on the direction of rotation of the sun's time. However, it does not have a time point on the speaker.

The other time deixis also showed the following quote.

7. Makkedai Datu e, "Wa, kessipaha Sabbarak! Cinamoha ri kamponna tau $e^{\prime \prime}$.

The king said, "Very well, Sabbarak! Briefly, you are in the land of people.

In data (7), there is time deixis, i.e., the word cinamoha 'briefly,' which points to the speaker, i.e., La Sabbarak and datu 'king.' In their conversation, La Sabbarak can buy a shop owned by the king. La sabbarak will pay twenty ringgit of gold even though La Sabbarak had not left for a long time. Thus, the word cinamoha 'briefly' marks as time deixis.

The next quote is also showing time deixis in Tau Sabbarak E.

8. Tuli terrini bainena, malalenni wenni e nadek naddibola. Tessiagai ittana engkani Lasabbarak lettu ri bolana. Riduppaini ri bainena. Napoccuini belle-belle. " Ia mitu bawang, pura uniakeng i tu ri laokku”. Uporennutu, lebbipi uporennunna watakkaleta". Na karena malalenna wenni e, matteruni bawang matinro. Tette asera ele e depa napasedding. Motomuni matua makkurainna. Aga tona napoleang. Engka mupi lewu, mabela-bela memeng dallek e nakko makkuiro". (SLB: 51) 
La Sabbarak's wife kept crying because her husband had not come yet. Not long after, La Sabbarak arrived at his house. His wife also welcomed him. He handed over a gift that was brought home, i.e., a can of fish. "That is the only achievement I have intended," said La Sabbarak. "I'm pleased to receive it, but even happier, I welcome you." Because it was late at night, they went to sleep. At nine o'clock the next day, La Sabbarak did not wake up. Said his mother-in-law, "What has he brought home? He still sleeps through now. How was the fortune would not be far away if his behavior were like that?

There is a deixis time in data (8), i.e., the word maleleng wenni 'late at night.' Unlike the time deixis tette asera ele e, 'nine in the morning' is time deixis because the point or time limit is apparent, i.e., La Sabbarak, which has not been awake at that time. Thus, the phrase malaleng wenni $e$ 'late at night' and tette asera ele $e^{\prime}$ at nine in the morning include time deixis.

\section{Conclusion}

Based on the results and discussions, it is concluded that the story of Tau sabbarak E has the second single person pronoun deixis, i.e., -mu 'you' at the words daengmu 'your brother' and lakkaimmu 'your husband.' There is also the first single-person pronoun, u- 'aku' at the words usiala 'I am married, uita 'I see,' and usukkuru 'I am grateful. ' In addition, there is also the third person pronouns plural, i.e., na- 'nya' at the words bainena 'his wife,' napalessokna lempakna' lowered the luggage,' kedona 'his attitude,' and indokna 'mother.' Furthermore, the second singular person pronoun appears in the word idik 'you,' which is found in the word idikmuto 'you too' refers to the female character 'mother.'

The second singular pronoun is also found in this story, which is -kik 'you' on the word amaingekkik 'be aware, mom! Then, self-naming deixis is found in the word toke, 'the name for men who seller in a Chinese shop,' and the word punggawa 'leader,' which refers to La Sabbarak. Another finding is the use of time deixis found seems at the word makkukkue 'now,' cinamoha 'briefly,' maleleng wenni 'late at night,' and tette asera ele e, 'nine o'clock in the morning.' In addition, the lexeme of time without deixis appears in the word pitungesso 'seven days.' In this research, no space deixis or locative deixis was found. Deixis research, a linguistic study that promotes Buginese oral-literary stories, is an effort to save local identities from extinction. The preservation of local identity will enrich the national cultural characteristics of the Indonesian nation.

\section{Acknowledgments}

The authors would like to thank the Balai Bahasa Sulawesi Selatan, which has given us a chance to conduct this research. We are grateful to be anonymous reviewers who have given marks, critics, and suggestions for this article's perfectness. This research is also dedicated to Buginese communities in South Sulawesi as informants on this research.

\section{References}

[1] A. S. Nursyirwan, "Mengukur kesiapan Kalimantan Tengah calon ibu kota baru," https://www.antaranews.com/berita/985420/mengukur-kesiapan-kalimantan-tengah-calon-ibu-kotabaru, 2019. [Online]. Available: https://www.antaranews.com/berita/985420/mengukur-kesiapankalimantan-tengah-calon-ibu-kota-baru. [Accessed: 01-Jan-2020]. 
[2] S. Riyandi, "4 Alasan Presiden Jokowi pindahkan ibu kota ke Palangkaraya," https://www.merdeka.com/, 2017. [Online]. Available: https://www.merdeka.com/uang/4-alasanpresiden-jokowi-pindahkan-ibu-kota-ke-palangkaraya.html.

[3] I. H. Suardi Lubis, Andri Suprayogi ST., MT *, "KESESUAIAN RENCANA TATA RUANG WILAYAH (RTRW) DENGAN PENGGUNAAN LAHAN KECAMATAN GAYAMSARI DAN KECAMATAN SEMARANG TIMUR,”J. Geod. Undip, vol. 2, no. 2, pp. 13-22, 2013.

[4] L. Z. and Z.-R. Peng2, "LandSys II: Agent-Based Land Use-Forecast Model with Artificial Neural Networks and Multiagent Model,” J. Urban Plann. Dev., vol. 141, no. 4, 2015.

[5] I. Díaz-parra, "International Journal of Urban Sciences A back to the city movement by local government action : gentrification in Spain and Latin America," no. May, pp. 37-41, 2015.

[6] S. S. Epi Syahadat, "PERMASALAHAN PENATAAN RUANG KAWASAN HUTAN DALAM RANGKA REVISI RENCANA TATA RUANG WILAYAH PROVINSI," J. Anal. Kebijak. Kehutan., vol. 9, no. 2, 2012.

[7] Garing, J, “Tense, Mood, and Aspect Systems in Tae' Language." Thesis. Radboud Universty of Nijemegen, the Netherlands, 2011.

[8] T. F. DJajasudarma, Semantik II Pemahaman Ilmu Makna. Bandung: Eresco, 1999.

[9] B. K. Purwo, Deiksis dalam Bahasa Indonesia. Jakarta: Balai Pustaka, 1984.

[10] Asriani Abbas, "Penggunaan Deiksis dalam Perahu Nuh II Karya Aspar," Universitas Hasanuddin, 2002.

[11] Nursiah Tupa, "Penanda Waktu dalam Bahasa Makassar," in Bunga Rampai Hasil Penelitian Bahasa dan Sastra, Ujung Pandang: Balai Bahasa Ujung Pandang, 1998.

[12] Hastianah, "Deiksis dalam Ungkapan Pakkiok Bunting dalam Bahasa Makassar," in Prosiding Seminar Bahasa Sastra dan Pengajaran, Ujung Pandang: Balai Bahasa Ujung Pandang, 2009.

[13] T. Mahendra, Z. Zainuddin, and H. Hamka, "DEIXIS IN NOVEL 'THE LAST STAR' BY RICK YANCEY,” English Educ. English J. Teach. Learn., 2018, doi: 10.24952/ee.v6i2.1262

[14] W. Afrilian, D. Rozelin, and A. Rahmi, "Deixis in Judith McNaught's Night Whispers Novel," Indones. J. EFL Linguist., 2019, doi: 10.21462/ijefl.v4i1.100.

[15] D. Suparno, “'Deiksis' dalam Kumpulan Cerpen Al-Kabuus Tinjauan Sosiopragmatik,” Bul. AlTuras, 2020, doi: 10.15408/bat.v21i2.3846.

[16] A. Fahruddin, Sastra Lisan Bugis. Jakarta: Pusat Pembinaan dan Pengembangan Bahasa, 1981 